\title{
Reconciled Community
}

\section{On Finding a Soteriology for Fresh Expressions}

\author{
Stefan Paas \\ Professor of Missiology and Intercultural Theology, Vrije Universiteit \\ Amsterdam \& Professor of Missiology, Theologische Universiteit Kampen, \\ Baambrugge, the Netherlands; Research Associate, Faculty of Theology and \\ Religion, University of Pretoria, Pretoria, South Africa \\ s.paas@vu.nl \\ Hans Schaeffer \\ Professor of Practical Theology, Theologische Universiteit Kampen, \\ Kampen, the Netherlands \\ jhfschaeffer@tukampen.nl
}

\begin{abstract}
Recent experience suggests that there is insufficient reflection on the 'why' of mission among missionary pioneers, that is, on the soteriology that underpins missional practices in the West. This article argues, first, that a social view of salvation is the best way to make theological sense of missional community formation (MCF). Second, this implied soteriology is further developed as an integrative lens on various dimensions of salvation in Christianity. Third, it is argued that this relocation of MCF in this social view of salvation offers rich opportunities for witness, and thus a potential remedy against soteriological embarrassment.
\end{abstract}

\section{Keywords}

community formation - discipleship - ecclesial practice - Fresh Expressions missiology - salvation 


\section{Introduction}

Recent years have witnessed the establishment of experimental forms of church all over Europe. These initiatives go by different names, such as 'Fresh Expressions of Church' in the United Kingdom, Erprobungsräume (experimental spaces) in Germany, and pioniersprojecten (pioneer projects) in the Netherlands. ${ }^{1}$ What they have in common is an explicit missionary purpose. These new Christian communities are 'established primarily for the benefit of people who are not yet members of any church' and focus on 'making disciples' (Fresh Expressions). They 'reach out to the unreached with the gospel and invite them to discipleship (Nachfolge)' (Erprobungsräume), ${ }^{2}$ or they 'intend to form a network or community where people can discover that God is love and wants to be close to us' (pioniersprojecten). ${ }^{3}$

Given these evangelistic goals, one would expect a clear rationale underpinning these practices. For example, if 'making disciples' is such an important objective, one would expect that beliefs about what is a disciple and why it is important to make disciples would be articulated and brought forward for debate. Or if 'discovering that God is love' is viewed as a core purpose for these projects, one might expect to hear more about the reasons why it is so crucial for late-modern citizens to encounter this loving God. However, this does not always seem to be the case. If the Dutch scene is in any way representative of other European countries, there is a worrying absence of reflection on the 'why' of mission as opposed to the 'what' and 'how'4

This lack of reflexive accounting may represent uncertainty among practitioners. Recent studies in the UK and in the Netherlands show that missionary pioneers often experience embarrassment with regard to their soteriological beliefs. ${ }^{5}$ This even raises the concern that Fresh Expressions may result in

1 On missional pioneering in the UK, the Netherlands, and Germany, see a.o. S. Paas, Church Planting in the Secular West: Learning from the European Experience (Grand Rapids, MI: Eerdmans, 2016). For recent German examples, see also Erprobungsräume: Kirche anders entdecken, ed. Evangelische Kirche in Mitteldeutschland (Erfurt, 2019).

2 https://www.erprobungsraeume-ekm.de/ueber-das-projekt/ (last accessed 26 November 2020).

3 https://www.protestantsekerk.nl/thema/missionair-werk/ (last accessed 26 November 2020).

4 Cf. S. Stoppels, Heil zien in missionaire initiatieven: Een zoektocht naar de theologie achter nieuwe vormen van geloofsgemeenschap (Ede: Lectoraat Zingeving CHE, 2O19), pp. 12-16.

5 C. Watkins and B. Shepherd, "The Challenge of "Fresh Expressions" to Ecclesiology: Reflections from the Practice of Messy Church', Ecclesial Practices 1 (2014), pp. 92-110; Ph. R. Wall, Salvation and the School of Christ: A theological-ethnographic exploration of the relationship between soteriology, missiology and pedagogy in fresh expressions of church ( $\mathrm{PhD}$ Thesis Kings College: London, 2014); S. Paas and M. Schoemaker-Kooy, 'Resilience and Crisis among European Church Planters', Mission Studies 35 (2018), pp. 366-388; Stoppels, Heil zien, pp. 15-16. 
'Jesus-less communities' ${ }^{6}$ Altogether, there seems to be little explicit soteriological reflection on the theoretical level and much soteriological insecurity on the ground. ${ }^{7}$

One of the reasons may be the general speechlessness about religion in the more secularized societies of the West. ${ }^{8}$ Another reason may have to do with the biographies of pioneers, who often come from an Evangelical background. Some (perhaps many) of them will have their first genuine encounters with non-Christians through their missionary experience, ${ }^{9}$ and this will likely affect their previously 'untested' beliefs. A lack of deep theological pockets may be a third reason, that is, 'soteriology' may be associated with doctrines the pioneer can no longer believe in, while alternative approaches remain unknown and therefore unexplored.

Whatever the reason (and perhaps it is a combination of reasons), this theological embarrassment is a serious challenge for Christian mission in the West. Christianity's missionary character has often been seen as the source of its vitality and its potential for reaching out to ever-new cultures and generations. ${ }^{10}$ At the same time, the rationale for Christian mission is deeply rooted in soteriology. Throughout its history, 'the Christian missionary movement has been motivated ... by the desire to mediate salvation to all.'11 To the extent that the future of religion depends on its ability to take its 'promise [of salvation] seriously' and 'represent it credibly', 12 the future of Christianity may be at stake here. This is not just a sociological observation; more than one missiologist has pointed out that Christian mission is in a state of 'crisis', and that this crisis has everything to do with a crisis of 'faith, spirit, and theological conviction'.13

6 Watkins and Shepherd, 'Challenge', p. 99.

7 Cf. J. A. Williams, 'Ecclesial Reconstruction, Theological Conservation: The strange exclusion of critical theological reflection from popular strategies for the renewal of the Church in Britain', Ecclesiology 11 (2015), pp. 289-305.

8 Cf. Paas and Schoemaker, 'Resilience'; A.A. Groza, 'The Seldom Acknowledged Difficulties of Leading Missional Churches: Challenges Faced by Those Who Seek to Explore Different Forms of Being and Doing Church', Ecclesial Practices 6 (2019), pp. 163-181.

9 Wall, Salvation, pp. 254-255.

10 Cf. A. F. Walls, The Missionary Movement in Christian History: Studies in the Transmission of Faith (Maryknoll, NY: Orbis Books, ${ }^{8} 2004$ ); S. B. Bevans and R. P. Schroeder, Constants in Context: A Theology of Mission for Today (Maryknoll, NY: Orbis Books, 3rd. edn, 2011), pp. $30-31$.

11 D. J. Bosch, Transforming Mission: Paradigm Shifts in Theology of Mission, (Maryknoll: Orbis Books, 24th edn, 2008, p. 393; cf. Bevans and Schroeder, Constants, p. 34.

12 M. Riesebrodt, The Promise of Salvation: A Theory of Religion (Chicago, IL: The University of Chicago Press, 2010), p. 184.

13 J. A. Scherer, Gospel, Church, \& Kingdom: Comparative studies in world mission theology (Eugene, OR:Wipf \& Stock, 1987), p. 33; cf. Bosch, Transforming Mission, pp. 1-11; L. Newbigin, The Gospel in a Pluralist Society (Grand Rapids, MI: Eerdmans, 2nd ed., 1999), p. 126. 
In sum, the embarrassment mentioned above is bound up with a deeper and more prolonged malaise of Christianity in the West.

In this article we present a soteriology for Christian missionary community formation (hereafter, MCF). In doing so, we take our cue from the definition of practical theology by John Swinton and Harriet Mowat: '[C]ritical, theological reflection on the practices of the Church, as they interact with the practices of the world, with a view to ensuring and enabling faithful participation in God's redemptive practices [missio Dei-sP\&JHs] in, to and for the world. ${ }^{14}$ First, we will explore what it means to see MCF generically as an intentional practice focused on disciple-making. We will argue that only by taking community formation and disciple-making as two sides of the same theological coin can a coherent soteriological vision for MCF be construed. Secondly, we root this understanding of MCF in a wider soteriological tradition of community and reconciliation. And thirdly, we propose that MCF as contextual praxis offers a hermeneutical space where soteriological questions and experiences will inevitably surface. Our objective is to assist practitioners in making theologically informed choices about soteriological beliefs that inform and inspire them, so that their spirituality is strengthened. After all, believing in what you do, and knowing why you do it, is crucial for everyone who embarks on a mission.

\section{Community and Discipleship}

Much like farming or parenting, MCF can be described as a practice in the MacIntyrean sense, that is, a 'coherent and complex form of socially established cooperative human activity through which goods internal to that form of activity are realized. ${ }^{15}$ There are at least three elements here to unpack. First, MCF's definition as a missionary practice depends on its institutional ('socially established') nature. Practices connect us with a tradition; they convey (often implicit) norms and rules. MCF is defined as a missionary practice because of its history, its institutional bedding and its formally stated goal of 'disciple making. This connects MCF with the greater Christian tradition and the apostolic age (Matt. 28:18-20). Here we must distinguish between the 'institutional beliefs' that make MCF meaningful and intelligible on the one hand and the

\footnotetext{
14 J. Swinton and H. Mowat, Practical Theology and Qualitative Research (London: SCM, 2006), p. 6 .

15 Alasdair MacIntyre, After Virtue: A Study in Moral Theory (London: Bloomsbury, 3rd edn, 2008), p. 224.
} 
personal beliefs of its participants on the other. Following Martin Riesebrodt and Christian Smith, ${ }^{16}$ we can say that MCF's missionary character as a religious practice is predicated on its cultural and institutional character. Just as even a thoughtless prayer, uttered by an agnostic, is still a religious practice, ${ }^{17}$ MCF is a missionary practice regardless of the beliefs of pioneers or visitors. 'Somebody somewhere needs to be able to explain at least some of the religious [missiological - SP\&JHS] significance of the actions', ${ }^{18}$ even if this 'somebody somewhere' is not participating in this particular pioneering initiative. Of course, this does not mean that the beliefs of participants are irrelevant, far from it (see section 4.1). However, the nature of MCF as a missionary practice is established institutionally and culturally before anything else.

Secondly, MCF connects its practitioners with a tradition of missionary community formation as a process of different steps. Traditional plantatio ecclesiae was conceived as a three-stage process of evangelism (conversion), gathering (baptism and community formation), and planting (constitution). ${ }^{19}$ Likewise, MCF is presented by its advocates as a 'journey' of several steps: 'listening', 'loving and serving', 'building community', 'exploring discipleship', 'church taking shape', and 'do it again. ${ }^{20}$ The rationale for this 'journey' is found in the increasingly secular character of Western societies, which requires a more prolonged stage of building contacts and gaining credibility. While it is claimed that each stage 'is valuable in its own right', the coherence of the various activities in the process is clearly sought in the opportunities for 'disciple making' that each stage has to offer. ${ }^{21}$ This makes sense, since we have seen that 'making disciples' (UK), 'inviting people to discipleship' (Germany), or helping people 'to discover that God is love' (the Netherlands), ${ }^{22}$ are the formal objectives of these pioneering projects. Taking our cue from William Abraham's definition

16 Riesebrodt, Promise, pp. 74-75; Christian Smith, Religion: What It Is, How It Works, and Why It Matters (Princeton, NJ: Princeton University Press, 2017), pp. 22, 26, 30.

17 Riesebrodt, Promise, pp. 87-89; Smith, Religion, p. 32.

18 Smith, Religion, pp. $3^{2-33}$.

19 Paas, Church Planting, p. 31.

20 M. Moynagh, Church for Every Context: An Introduction to Theology and Practice (London: SCM Press, 2012), p. 208.

21 Moynagh, Church, pp. 209-210.

22 One wonders to what extent these different phrasings might be explained by different cultural contexts. From oral communication we understand that the word 'discipleship' was received quite negatively within the context of the Dutch Protestant Church, thus leading to the different phrasing 'discover that God is love'. Apparently, 'discipleship' and its cognates were understood as too 'evangelical', too 'pious', or too 'free church'. 
of evangelism as initiation we might thus construe MCF as a set of intentional activities governed by the goal of disciple making. ${ }^{23}$

Thirdly, this approach immediately raises the question how then 'disciple making' (or an 'encounter with a loving God') relates to 'building community'. In MacIntyrean terms, this is an attempt to distinguish between MCF's 'internal' and 'external goods'. One way to go about this is to take 'community building' as a means to the end of 'making disciples'. A sociological argument for this could be that in most cases 'belonging' precedes 'believing'. Theologically, it may be argued that the exemplary life of the Christian community is God's preferred instrument of evangelization, and therefore the community should invite seekers to join the community even before they are Christians. This approach would sit well with a theology where God's mission is identified as 'saving souls', with salvation being predicated on individual conversion and exemplified in church growth, while a strict distinction between Christians and non-Christians is maintained. It is, however, difficult to reconcile this approach with the statement that community building is 'valuable in its own right. ${ }^{24}$ What, after all, is the intrinsic value of community if it is instrumentalized towards the supposedly higher purpose of making disciples? Doesn't this imply that every element of community building (friendship, forgiveness, hospitality, patient listening, serving one another, etc.) is eventually determined by the overt or covert agenda of disciple-making? And wouldn't this sooner or later undermine the integrity of community building within MCF practices?

Therefore, a better way to integrate the formal goal of 'disciple making' and the 'pioneer journey' where every stage has intrinsic value, is to see community building and making disciples as two sides of the same soteriological coin. Referring to Aristotle, MacIntyre claims that 'the creation and sustaining of human communities - of households, cities, nations - is generally taken to be a practice' in itself. ${ }^{25}$ Such practices require virtues like truthfulness, justice, courage, willingness to forgive, humility, love. By contrast, such practices are frustrated by vices or sins like self-centeredness, arrogance, pugnaciousness, hypocrisy, and exploitation of others. Reading through St. Paul's letters, one can hardly fail to see that such virtues and vices are crucial to any concept of Christian discipleship. It seems, therefore, that 'community' is only

23 Cf. W. J. Abraham, The Logic of Evangelism (Grand Rapids, MI: Eerdmans, 2nd edn, 1999), p. 95. Or, for that matter, '... the goal of leading people into an encounter with the love of God'. It is the missionary intentionality that concerns us here, not the exact phrasing.

24 Moynagh, Church, p. 209.

25 MacIntyre, After Virtue, p. 224. 
instrumental to 'discipleship' if the latter is taken a-socially, that is, as essentially an individual form of Christian life.

This brings us back to soteriology. Is salvation essentially an individualistic (an a-social) event, or is it inseparable from restoring our personhood as social beings? Theological consistency leads us to assume that a coherent approach of MCF as a missionary practice requires a soteriology that takes the relational dimensions of salvation seriously. In the next section we will attempt to sketch the contours of such a soteriology.

\section{Salvation and Community}

We have argued that MCF's missionary logic assumes a social view of salvation. In this section we consider to what extent this view is theologically responsible. We will argue, first, that the Christian tradition has always been flexible and contextual about its soteriological beliefs. Secondly, we will argue that a social soteriology provides an integrative lens on the various models of salvation found in the Scriptures. And thirdlywe will discuss how this lens brings issues such as discipleship and conversion into focus.

\section{Salvation in Christian Theology}

While salvation is a core topic in the Bible and the Christian tradition, ${ }^{26}$ an authoritative and ecumenical theory of salvation was never developed in the early church. ${ }^{27}$ However, virtually all Christian traditions are agreed on the intimate association of the work of salvation with the ministry of Jesus Christ, the 'Saviour' ( $\sigma \omega \tau \dot{p} \rho)$. Apparently, this association has been so self-evident that it has never been seriously contested or rejected by any important current in Christian thought (unlike other doctrines such as the Trinity or the two natures of Christ). As a consequence, the Creeds of the Church do not formulate a definition of salvation nor do they provide a universally accepted soteriology. The Nicene Creed, for example (version AD 325), says no more than: '[Christ]

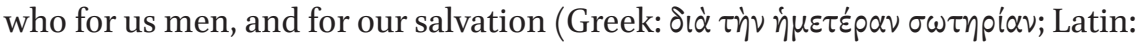
propter nostram salutem), came down and was incarnate and was made man.' While several Christian traditions have tried to establish a once-and-for-all

26 G. O'Collins, Jesus Our Redeemer: A Christian Approach to Salvation (Oxford: Oxford University Press, 2007), p. 1.

27 D. H. Williams, 'Patristic Theologies of Salvation', in: J. S. Holcomb (ed.), Christian Theologies of Salvation: A Comparative Introduction (New York: New York University Press, 2017), pp. 11-21, at p. 11 . 
doctrine of salvation (pedagogical, forensic, liberationist, etc.), 'each moment, era, and epoch raises different questions about the nature, means, methods, purpose, and effects of salvation. ${ }^{28}$

The New Testament reflects this under-defined and contextual nature of salvation in its multi-faceted presentation of God's saving presence, and its refusal to present a coherent theological treatise on salvation. Even though the New Testament and the vast majority of Christians see salvation as being bound up with the ministry and death of Jesus Christ, the wealth of metaphors associated with Christ's death on the cross testifies to the multifaceted character of salvation. ${ }^{29}$ This does not mean that there is no shared structure. An important study, while emphasizing the theological variety of salvation, mentions the following building blocks in the New Testament: ${ }^{30}$ (a) anthropologically humans are seen as in trouble in their relation to God (separation, alienation, enmity, guilt, death, captivity), and they are unable to solve this problem; (b) God comes in action and opens real possibilities for the restoration of relationship with him, motivated by grace and love; (c) the way this happens is described by a variety of images (ransom, new birth, sacrifice, liberation, etc.), which are all linked to the Christ-event; (d) certain conditions and consequences are linked to this salvation: obedience, behaviour that befits the new family of God, etc.; (e) believers are already experiencing the presence of the new era. These building-blocks make it clear that salvation, according to the New Testament, is not a theory to be understood or an object to be grasped. Salvation is first and foremost an event that relates people to one another and to God in time and space. From the perspective of practical theology and missiology, this fact is particularly interesting as it raises the question how salvation is experienced in and through practices, and how the experience relates to the other dimensions of salvation mentioned above. In short, the Christian tradition leaves ample room for a flexible approach to soteriology. Precisely this allows for mission as contextual witness and practice. At the same time, every soteriology that claims to be 'Christian' should explain how its view of salvation is rooted in the ministry of Jesus Christ (his life, death and resurrection), and how this affects inter-human relations. Therefore, 'Jesus-less' missional communities are an oxymoron.

28 Holcomb, Christian Theologies, p. 2.

29 Cf. Collins, Jesus; F. Rutledge, The Crucifixion: Understanding the Death of Jesus Christ (Grand Rapids, MI: Eerdmans, 2015).

30 J. G. van der Watt, 'Soteriology of the New Testament: Some Tentative Remarks', in: J. G. van der Watt (ed.), Salvation in the New Testament: Perspectives on Soteriology (Leiden: Brill, 2015), pp. 505-522; cf. J. D. G. Dunn, Unity and Diversity in the New Testament: An Inquiry into the Character of Earliest Christianity (London: sсм Press, 2006), pp. 30-31. 


\section{Jesus, the Kingdom, and the Restoration of Community}

The reconstruction of MCF's implicit soteriology above resonates with much of contemporary theological thinking about salvation and mission. In some important ways, section 2 already provides a reason why community formation is so crucial. In theological terms, creating community is a matter of salvation; it connects us with what God is doing to save the world. To lose sight of this soteriological horizon would easily turn mission into a matter of institutional survival rather than a genuine work of faith, hope and love. ${ }^{31}$ We will now proceed by arguing that 'community' not only offers a soteriological horizon for personal discipleship but presents us with an integrative lens on various dimensions of salvation as well.

What is salvation about? Within the limited space that is available here, we propose to view salvation as the restoration of community. Following Michael Gorman's analysis of Biblical covenant traditions, God's work of salvation can be construed as creating 'a liberated and forgiven community, a faithful, loving, and peaceable people empowered by the Spirit to bear witness to the holy character of God, to God's own faithful love and shalom' ${ }^{32}$ In this study, Gorman explores in great detail how this work of community building is the core of Jesus' kingdom preaching, and how this peace-making is proclaimed by the apostles as the effect of Christ's death on the cross.

This relational view of salvation resonates well with a long missionary tradition that is anticipated by Biblical promises about the prince of peace who will rule from sea to sea and until the ends of the earth (Zech. 9:10; Ps. 72:8). This, a community in time and space, is what God's kingdom is about. As Lesslie Newbigin has emphasized, mission happens in the time between Christ's first and second coming and is therefore a work of hope. The community that is the church has as 'its distinguishing mark ... the clear vision of the goal of history namely the reconciliation of all things with Christ as Head - and the reassurance that this goal will be reached. This is what gives its distinctive character to the Christian hope. ${ }^{33}$ According to Newbigin, '[t]he New Testament evidently envisages [this] goal' as 'one towards which we can make progress. "Now is salvation nearer than when we first believed", says Paul (Rom. 13:11). There is an eschatological relationship between community formation here and now and the future reconciliation of all things in Christ. In this sense, our attempts

31 Cf. B. Stone, Evangelism after Christendom: The Theology and Practice of Christian Witness (Grand Rapids, MI: Brazos Press, 2007), p. 153.

32 M. J. Gorman, The Death of the Messiah and the Birth of the New Covenant: A (not so) New Model of the Atonement (Eugene, OR: Cascade, 2014), p. 43.

33 Newbigin, Gospel, p. 101. 
at community building can be seen as 'acted prayers for the kingdom'. Through the Holy Spirit, as 'power veiled in weakness', community formation is a 'firstfruit' or a 'foretaste' of the kingdom. ${ }^{34}$

If the missio Dei is essentially about bringing about the kingdom of peace and if MCF can be seen as participation in and anticipation of this mission of God, then it makes sense to construe MCF as a contextual missional practice of reconciliation. This echoes the twentieth-century 'Copernican turn' (David Bosch) in missiology towards kingdom-oriented (eschatological) models of mission. ${ }^{35}$ Typically, such models of mission are 'heavily influenced by a discernment of God as active in human history'. ${ }^{36}$ Moreover, salvation is not limited to individualistic and spiritual salvation post-mortem, or postponed to Judgement Day, but it is also experienced in the here and now, and it includes social and physical liberation.

This approach would mean, then, that MCF starts with the theological assumption that God is at work wherever a reconciled community is in the process of being created, and that salvation is happening wherever this is experienced (more on this below). This focus on community has the potential of integrating a whole range of topics related to salvation. Evidently, this is true for soteriological models that explicitly revolve around personhood and koinonia, as in the work of John Zizioulas. ${ }^{37}$ Here, salvation means to become an 'ecclesial person',38 that is, someone who grows into the image of the trinitarian God. Salvation, first and foremost, is about becoming a person, a more social being, somebody who is capable of living in loving relationships. Therefore, the restoration of our social nature is a crucial part of what it means to be 'saved'. In this way, 'building community' is an essential dimension of salvation, particularly when 'community' is interpreted as a space defined by relationships, where we can learn to love and be loved, to serve and be served. With reference to Lesslie Newbigin's famous quip about the congregation as a hermeneutic of the gospel, ${ }^{39}$ we might say that at the very least the building of a community

34 Ibid., pp. 110, 115, 119-120.

35 Cf. R. Hardmeier, Kirche ist Mission: Auf dem Weg zu einem ganzheitlichen Missionsverständnis (Neufeld Verlag: Cuxhaven, 20o9); W. Morris, Salvation as Praxis: A Practical Theology of Salvation for a Multi-Faith World (London: T\&T Clark, 2014).

${ }_{3} 6$ E. Graham, H. Walton and Frances Ward, Theological Reflection: Methods (London: SCM Press, 2005), p. 171.

37 Cf. S. Paas, Pilgrims and Priests: Christian Mission in a Post-Christian Society (London: SCM Press, 2019), pp. 187-207; Morris, Salvation, 123-126.

38 J. D. Zizioulas, Being as Communion: Studies in Personhood and Church (Crestwood, NY: St. Vladimir's Seminary Press, 1985).

39 Newbigin, Gospel, pp. 222-233. 
opens up a hermeneutical space in which we can discover and explore God's salvation. The community is structured as a fellowship of people (horizontally) that in a certain way reflects the trinitarian community (vertically).

It is because of this intrinsic relation between the horizontal and vertical relationships that these relations can be called community on the one hand, as relationships cannot exist in the abstract. Yet, on the other hand, this community is missional, since it is participating in the mission of God, and therefore its boundaries are porous. It is always open to invite, include, connect and learn. In other words, this community is not a source of identity ('us' versus 'them') and thus potentially divisive and hostile; it is a fundamentally porous space where people learn to explore their nature as relational beings, and thus to discover their identity in God, as a gift.

Community building as participation in the mission of God brings other dimensions of salvation into focus as well. In his Salvation as Praxis, for example, Wayne Morris explores three soteriological paradigms: deification (essentially, the koinonia vision sketched above), healing and liberation. ${ }^{40} \mathrm{He}$ does not attempt to integrate these three paradigms, as his focus lies on the potential of each paradigm to foster non-exclusive interreligious relationships. However, it does not require much theological imagination to see how healing and liberation are contingent on a soteriological vision of God's mission as creating a reconciled community. Such a soteriological vision is embodied in Jesus' actions, as Morris points out. The healing narratives in the Gospels portray Jesus as particularly concerned with the dignity of human beings as members of society. Healing is not necessarily about the 'normalization' of disabled persons, according to the standards of the fit and able-bodied. Morris argues that the 'embodied well-being of the person' in these healing narratives reflects 'a concern ... with overcoming marginalization and isolation'. Morris points to Jesus' question to a deaf man: 'What do you want me to do for you?'. The healing praxis of Jesus thus informs communities not to silence the voices of minorities or those who are isolated. 'The healing narratives are less of an imposition of a form of normativity onto anyone, but rather a radical subversion of practices of exclusion, marginalization and isolation. ${ }^{41}$

Social marginalization is often interlinked with situations of poverty and oppression. Salvation as liberation addresses such evils as hostile to the kingdom of God. Again, it is the vision of reconciled community that brings this soteriological paradigm into focus. Eventually, releasing persons from poverty and oppression is oriented towards the creation of just communities, and the

40 Morris, Salvation, pp. 111-176.

41 Ibid., pp. 145, 147. 
transformation of human beings who can be friends with one another and with God. ${ }^{42}$ In other words, both illness and oppression are forces that oppose the mission of God towards reconciled community. Participation in this mission means to build communities where people can become friends in a world rife with injustice. Again, such communities would necessarily take an eschatological, hopeful shape ('power veiled in weakness'), since violence, racism and oppression will be with us until the end of time. Yet, every step towards friendships rooted in equality and justice must be welcomed as a foretaste of the kingdom of God.

To sum this up, our reconstruction of MCF's implicit soteriology is underwritten by a theological vision of God's mission as oriented towards the restoration of community. Other dimensions of salvation, like healing and liberation, are eventually intentional towards the creation of community. The fulfilment of God's kingdom is a reconciled humanity, living in peace with one another, with God and his creation. MCF as a contextual practice begins with the discernment of God working towards community in concrete settings where isolation, self-centeredness, illness and various forms of injustice hinder the realization of community. Participation in the mission of God means to participate in the eschatological kingdom ministry of Jesus, by empowering and liberating people, as a hopeful community that welcomes every sign of the kingdom amidst pain and injustice. To be saved, in short, means to become a 'community person', a person capable of loving friendship through a process of transformation that includes moral change, empowering, liberation and healing. This is what it means to live through the Spirit, together with others, in the realm of God's kingdom. This is, in the end, what keeps together the whole New Testament soteriological vision.

\section{Cross and Resurrection}

So far, we have linked our reconstruction of MCF's soteriology with the kingdom ministry of Jesus, his acts and words of liberation (in various forms) and healing. We have argued that the building of community is a participation in the mission of God and thus an eschatological foretaste of the full realization of his rule. Where does this leave us in relation to Jesus' death and resurrection? How can MCF be a hermeneutical space where testifying about the cross and the resurrection makes sense? In other words, how can Jesus' death and resurrection - the crucial events of Christian faith - make sense in the daily struggle of building community amidst various forms of injustice and inequality? Only 
a firm confidence that they do make sense can release the boldness ( $\left.\pi \alpha p p \eta \sigma^{\prime} \alpha\right)$ to articulate the name of Jesus in 'Jesus-less communities'.

Here we reach the point where the rubber hits the road. Speaking about community formation may sound very relevant in societies that suffer from deep polarization. The vision of the peaceful kingdom may touch us profoundly, and inspire us as a truly valuable mission to invest our lives in. But any Christian view of salvation worth its salt cannot avoid questions of sin and repentance, powers and liberation, transformation and discipleship. Communities are formed out of people whose lives are battlegrounds of virtues and vices, and in societies where dark forces drive us apart. In many ways, building community is a frustrating task. Therefore, if MCF is to be a place of witness, it must tap into the language associated with Jesus' cross and resurrection - the language of suffering, unconditional love, forgiveness, healing, and victory over evil.

One problem is that the salvation brought about by the cross has often been associated with an individualistic and vertical soteriology that concentrates on rescuing people from $\sin (\mathrm{s})$ that block their future way to heaven - sins they have committed and the original sin of Adam. To be saved, then, means to believe in Jesus and accept the grace of forgiveness wrought by his death and resurrection. Part of the problem with this view of salvation is that it is often bound up with an exclusivist view of salvation as 'only for Christians'. Another, related, part of the problem is that the salvation thus offered is often isolated from bodies and social contexts. In missional praxis this easily leads to situations where non-Christians who fight injustices are considered as 'unsaved', while Christians (that is, those who have confessed Jesus) who live selfish and unjust lives are 'saved'43 In short, it is difficult to see how such an individualistic, exclusivist and post-mortem vision of salvation genuinely connects with the communal soteriology that is implicit in MCF. This may explain why many practitioners, particularly those from an Evangelical background, experience soteriological embarrassment when embarking on MCF. Possibly, they have a hard time explaining 'sin' as whatever blocks the realization of true community (rather than blocking our post-mortem path to heaven), and they are hesitant in seeing 'salvation' as whatever contributes to building community.

However, if salvation were nothing more than imitating Jesus in his kingdom ministry, another problem presents itself. This is the classic problem of liberal Christianity, namely, of becoming a Christianity for those who are morally well-to-do, who can work out their own salvation quite well - even if with some effort and discipline. In the end, this would lead to a bourgeois soteriology where people save themselves, hopefully with some help from

Cf. Ibid., pp. 159-16o. 
God. And this easily leads to communities that are either speechless in the face of their own failure to meet progressive standards in the name of Christ or, worse still, transform into a politically correct judgementalism parading as prophetic witness. In short, here the problem does not lie in accepting that community-building means participating in God's mission, but in accepting that building community confronts us with sin and evil to such an extent that we become powerless. This is usually easy to ignore, of course, because so many of our communities are really peer groups and societies of the like-minded.

So how are Jesus' cross and resurrection related to a missiological praxis of community building? To begin, there is a way in which salvation 'happens to us' rather than is performed by us, when we move into the realm where community building happens. As Robert Schreiter has worked out in a way somewhat different from ours, to embark on the ministry of reconciliation means to enter a space in which God works to transform us, or rather 'save' us, to become people of peace. ${ }^{44}$ So, in a general way MCF is a space where we are 'objectively' impacted by what God has done for us, regardless of our 'subjective' beliefs. At the same time, we should note a rather self-evident truth: not much transformation will be witnessed when there is little to reconcile. In other words, to the extent that communities build on existing social categories that link people together by bonds of blood, soil, ethnicity, education, moral performance, political views, and social class (so-called 'homogeneous units') not much reconciliation is expected to happen. It is where human action falls short, where it is swamped in sin and death, where otherness and estrangement are experienced, that God creates something new out of nothing. As Andrew Root works out in his study of a practical theology of the cross, 'human impossibility' is the 'very arena of the possibility of divine action'.45 God's mission takes place in the tension between the kingdom vision of a reconciled humanity on the one hand and our impossibility to build genuine community in a world so full of conflict. The word of the cross does not make much sense unless we enter the realm of genuine community building, that is, the realm of human impotence. Embarking on community building is to enter a cruciform yet hopeful space.

All this means that MCF embodies a reality that makes sense soteriologically when the language of suffering, sacrifice, costly love, and victory over death and sin through Jesus' resurrection applies. Community formation in the sense we have described above opens a divine space where the reality can

44 R. J. Schreiter, The Ministry of Reconciliation: Spirituality \& Strategies (Maryknoll, NY: Orbis Books, 1998).

45 A. Root, Christopraxis: A Practical Theology of the Cross (Minneapolis, MN: Fortress Press, 2014), p. 119 . 
be tasted that this world was 'created in Christ', that is, a world participating in his cross and victory. In building community, we are constantly brought up short by the real challenges involved in this within actual neighborhoods and societies. In participating in God's mission of reconciliation (cf. 2 Cor. 5:18-19), we are facing our need for a transformation that lies beyond our possibility. Think of the following questions:

1. How will victims and perpetrators live together? Can there be peace without justice? Can there be justice without vengeance?

2. What does this mean for people of different social class and ethnic background? How can peace become real in a world with huge differences in power, a world bleeding from deep colonial wounds?

3. Will peace ever exist between people of different origin, sexual orientation, men and women? What about the scars, the long history of patriarchy, oppression, the resentment ensuing from this?

4. How will idealists ever be able to truly love those who oppose their lofty ideals, or who are unable to live up to these expectations? How can they avoid becoming new Jonahs preaching judgement to contemporary Ninevehs?

5. Is it possible to build a community that includes both the strong and the weak?

Such questions bring us up short in the sense that they confront us with real limitations and paradoxes. They make us realize that community building is a thoroughly eschatological task which, at best, yields 'acted prayers for the Kingdom' (Newbigin). These questions cannot be answered intellectually but need to be engaged in all dimensions of our human existence: theologically, socially, spiritually, physically, economically. Driven by these questions and challenges, Christians are led to re-discover their soteriological scripts, that is, the paradoxes, promises and messages bound up with the cross and resurrection of Jesus. And in doing so, they may discover a renewed boldness.

Finally, it is important at this point to underline what has often been said in studies of Christian soteriology: the cross is not an attempt to move a wrathful God into pity for human beings by showing him the blood of his innocent Son. Much has been said about this rather crude theory of 'divine child abuse' that doesn't need repetition here. Reconciliation is a divine initiative from beginning to end. 'All is from God', says Paul, 'who through Christ reconciled us to himself' (2 Cor. 5:18). In other words, the Father is acting, 'not over against the Son, but through and in the Son, whose will is the same as the Father's. ${ }^{46}$ So, there is no 'rift' within the hermeneutical space opened by MCF. There is no

46 Rutledge, Crucifixion, p. 100. 
'kingdom ideal' of community that functions as a divine 'law' that must be fulfilled. This would mean that the cross becomes a 'satisfaction' we must appropriate in order to 'pay' for our shortcomings in meeting the kingdom standard. There would be a rift within MCF, that is, its space would be divided between a space $A$ where humans try to meet the kingdom standard on their own and a space B where God is encountered to forgive their failure in space A. On the contrary, this soteriological space is without seam or rent: God transforms all those involved through his Son into the direction of the kingdom. Let us reiterate, embarking on community formation with sinful and broken people and in a warring world means entering a cruciform space. It is, in a very real way, what it means to be crucified and resurrected with Christ, to participate in his suffering and glory. Wherever people embark on the journey of reconciliation, God works his salvation from their very first attempts to their final breath. Being involved in MCF in the sense sketched here is to move into the realm of God's salvific action. God does not need reconciliation (God's will to save is eternal and indestructible), but we do. We must be prepared for life in the kingdom, and this preparation is what reconciliation is about. Reconciliation is about the transformation we need so that we can live in love with God and our neighbour.

So, in the hermeneutical space opened by MCF, the cross must be interpreted as the way through which God reconciles us with his kingdom rather than himself with us. It is through the cross and the resurrection of Jesus that God heals, forgives and transforms us so that we are able to love. We can only become 'persons' when we grow into the awareness that we are truly loved, that the powers are judged and conquered, that no sin in us is stronger than the kingdom, that nothing on our part is needed to bring about God's future, and that all evil will work out for the good. All this and more is what the cross communicates - not primarily in words but in a deeply emotional, transforming, heart-rending drama that is meant to draw us in and to move us toward love.

\section{Missional Community Formation as Contextual Practice}

So far we have unpacked the implied missionary logic of MCF as a relational soteriology, whereby building community and making disciples are two sides of the same coin. Community formation is participation in the reconciling mission of God. We have argued that MCF makes most sense when it is viewed as an orthopraxy-driven approach of mission. That is, it is an approach firmly rooted within a soteriology of reconciliation and focused on the transformation of human beings to become capable of friendship. Building community is a 
deeply Christian task, and in participating in community building we are being saved for God's kingdom. This salvation is not based on our achievements; it happens in the tension between human impossibility and God's possibility. It is here where the language about Jesus, his cross and resurrection, begins to make sense. MCF is therefore more likely to be a 'Jesus-filled' experience when it is directed toward the healing of real conflicts and rifts rather than building comfortable communities of the like-minded. In this final section we will address some remaining questions that may have emerged. First, we will discuss briefly the potential tension between institutional and individual beliefs. Second, we will look more closely into the issue of conversion. And finally, we will look at possible practices of MCF.

\section{Institutional and Individual Beliefs}

We have already emphasized that our reconstruction of the soteriology of MCF pertains to its institutional significance. Here we should reiterate that this institutional intention (discipleship as community building) may be quite different from the individual intentions of those who participate. However, while our reconstruction of MCF's logic as 'missionally meaningful' is primarily rooted in its institutional significance, it is to be expected that its causal effects correlate with the level of intensity and understanding with which MCF is practised. ${ }^{47}$ A missionary who is just going through the motions, without enthusiasm or sacrifice, is not likely to meet much response. For an exploration of missionary practice, it is, therefore, crucial to tease out the actual beliefs of those who initiate them and bring these beliefs into dialogue with the institutional meanings that animate this practice.

Let us return, by way of example, to the soteriological embarrassment sketched in the introduction. Wall suggests that practitioners whose operative beliefs are rooted in a soteriological model that emphasizes individual confession of doctrinal truth as a precondition of salvation will find it difficult to work within a missional practice that is characterized by missio Dei thinking. 48 After all, there is little theological space in such a view to engage the idea that there may be salvation outside the church (see further below). A more obvious inconsistency may lie in the individual soteriology of this traditional evangelicalism versus the communal soteriology implied by MCF. The problem of 'covert agendas' (instrumentalizing community, love, service, etc.) may create serious tensions for practitioners working from this set of assumptions. An additional challenge, related to the wider cultural context rather than to

47 Cf. Smith, Religion, pp. 92-99.

48 Wall, Salvation, p. 39. Cf. pp. 23-32. 
MCF in particular, is the fairly authoritarian pedagogy of this model. It is to be expected that evangelical practitioners will find it increasingly difficult to work with this approach among contemporary Western audiences. ${ }^{49}$ Given the paradoxical fact that MCF has been 'most keenly adopted by those who adopt a redemption-centered theology',50 this might explain some of the embarrassment many pioneers feel.

An important challenge for MCF is thus how individual beliefs of participants can be aligned with the implicit soteriology of MCF. A crucial comment to be made here is that practices are not merely expressions of beliefs; they are also formative in the sense that they shape our beliefs. ${ }^{51}$ Therefore, if our reconstruction of MCF's implied soteriology makes sense, it is to be expected that practitioners will be shaped by this soteriology - and in fact, this is what happens. ${ }^{52}$ An important question to be asked is thus to what extent and under which conditions the process of community formation itself instils and transforms the beliefs of practitioners. Which tensions does it create with those operative beliefs? Are these tensions destructive and paralyzing or can they be rendered creative and enriching? As we have set out above, MCF will likely have more formative power when it finds the realm of human impossibility, that is, when it engages with genuine conflict and injustice, and makes sense of what happens through a theological framework of hope and receptivity.

49 Recent Dutch research indicates that this approach seems to work best in communities that work among immigrants and refugees. See S. Stoppels et al., Tussenstand pionieren: Sociale verbondenheid en geloofsontwikkeling bij deelnemers aan pioniersplekken (Utrecht: Protestantse Kerk in Nederland, 2020). English translation https:/www.researchgate.net/ publication/341521344_PIONEERING_STATE_OF_AFFAIRS_The_impact_of_pioneering on_social_cohesion_and_religious_development (last accessed 18 February, 2021). In general, it is to be expected that an authoritarian missionary pedagogy will flourish most in contexts where there are considerable differences in power between missionaries and target audiences, or in contexts where - due to previous religious socialization - there is a hunger for a more intellectually satisfying version of the faith. The latter can be found, for example, in some fast-growing evangelical churches in metropolitan areas that attract a sizable number of newcomers to the city who have been raised in more traditional Christian environments outside the city.

$50 \quad$ Wall, Salvation, p. 39; cf. Ch. B. James, Church Planting in Post-Christian Soil: Theology and Practice (New York: Oxford University Press, 2018), p. 29.

$5^{1} \quad$ Smith, Religion, pp. 44-46.

52 Cf. Wall, Salvation, pp. 236-237. Wall relates how engagement with missional praxis helped missionary practitioners in his research 'to reflect upon and move away from the soteriology advocated by the churched environment in which they grew up. That is, they moved away from an individualistic, other-worldly soteriology to a more inclusive, this-worldly and communal soteriology. 


\section{Community and Conversion}

Our reconstruction of MCF as a contextual praxis lays the emphasis on Christianity as a way of life rather than as a set of beliefs. Salvation is found in action; it means to have our lives oriented towards the kingdom of God that breaks in to our world. As such, salvation cannot but be holistic, this-worldly and communal. ${ }^{53}$ Missiologically, this approach strongly affirms God's mission in and through the world. 'God is active and redemptive outside the visible Church.'54 This opens up the question of conversion. What does conversion mean in this soteriology? At the very least, it would mean to turn towards reconciliation, that is, to open oneself up to the transformation that is needed to become a person of peace. Given what we have set out above, this would imply a commitment to enter the realm of human impossibility where God works his salvation. While it may be debatable to what extent the ideal of a reconciled humanity is available outside the kingdom vision that has been declared by Jesus, from a Christian perspective it makes little sense to speak of God's action in our impotence without relating this to Jesus. The point is, of course: can this salvation be had without actually confessing Jesus, even if it is unavailable without him? In other words, does entering the 'soteriological space' of MCF (as set out above) count as conversion to God and his Christ, even without actually confessing Jesus or even believing in God?

Many would say that salvation in this approach is not reserved for Christians; it includes all people who live their faith with integrity and in the service of humanization, justice and peace. ${ }^{55}$ To be clear, this does not necessarily amount to 'universal salvation'. After all, there are people - Christian or not - who do not live their life in the service of humanization, justice and peace. It sits well, however, with a position of inclusivism, the view that the work of Christ benefits all those who participate in his kingdom mission, regardless of whether they know or recognize it. This may very well be the soteriological default position of many MCF initiatives that focus on praxis models of mission.

Christopher James, for example, in his ethnographical study of new churches in Seattle, points out how the 'Neighborhood Incarnation' (NI) church concentrates on the upbuilding and strengthening of local community as an eschatological sign of the kingdom of God. Hospitality, the establishment of 'third places', and the creation of humanizing relationship are the preferred missionary practice of N I churches. A significant challenge, according to James, is

53 Wall, Salvation, pp. $75^{-76}$.

54 Wall, Salvation, p. 74.

55 Wall, Salvation, p. 76: cf. Morris, Salvation. 
'the possibility that NI churches would lose their distinctively Christian and/ or ecclesial identity and become little more than social service or community development agencies' ${ }^{56}$ This problem may be most urgent among missionary practitioners from low-church of free-church backgrounds, as their communities usually lack the liturgical structure that is self-evident in High-Church environments or in monastic communities such as Sant'Egidio. The challenge arising from this context is how to create 'a learning environment in which beliefs and stories of the unchurched are heard, welcomed and learnt from alongside those of the Church'.57 Similarly, James advocates the inclusion of formal Christian learning and initiation ('worship, prayer, personal holiness, and proclamation') and a critical reflection on the cultural context, leading to define sin not just in progressive categories such as inequality and racism but also in more conservative categories such as 'personal sin'.58 Again, this points to a deeper reflection on the character of the missio Dei and what it means to participate in this mission.

From a more 'confessional' perspective, legitimate questions can thus be asked to this praxis-oriented approach of reconciliation. Is there a place for faith and praise of Jesus? What about spiritual powers? Is this community building a space that we construct, or a truly sacramental space of God's presence? Can we ever become 'people of peace' without experiencing that we are deeply loved and forgiven? How do we avoid that an idealistic project of reconciliation will end in arrogance and hostility towards 'others' who are more conservative or progressive, who vote differently, or are just plain nasty? Is that even possible without the cross where Christ died for victims and perpetrators? Will our wounds be healed? How can we ever forgive others, or even love our enemies? How can we become more empathetic towards others who are so different? Might we need exorcism? What does it require to become humble, hospitable, willing to learn? How shall we keep hope that God is indeed active in mission, without constant reorientation toward his story? And how can we learn to understand the community that takes shape as a place of encounter with God, the Body of Christ, a eucharistic event? In short, community building that is more than mere 'networking' - community building that crosses boundaries and brings together people from different backgrounds and political persuasions, is a constant space for witness, prophesy, critical reflection and debate, personal exploration, confession and forgiveness. The

56 James, Church Planting, pp. 171, 136, 176. Cf. Wall, Salvation, p. 246.

57 Wall, Salvation, p. 247.

58 James, Church Planting, p. 177. 
most important question, therefore, may not be whether salvation depends on a personal confession of doctrinal truth concerning God and Jesus, but to what extent the space opened by MCF will become a space where the name of Jesus can be mentioned without embarrassment, in full confidence that his name is truly good news to the challenges at hand.

Finally, this approach leads to a relativization of 'church' as a bounded community. After all, community formation is never finished, it is constantly in flux towards the eschatological realization of God's kingdom. By logical extension, such a community could never be something which is 'possessed' by the initiated and then 'offered' to the uninitiated. This would render community building instrumental again, as something that has been 'worked out' and 'controlled' by Christians and henceforth presented to non-Christians with the purpose of making them disciples. Also, the church is not a 'holy' community in the sense of 'being more successful than the world in creating community'. On the contrary, in accepting the call for reconciliation, in its actual struggle with community building - including its many failures - the church displays to the world the human impossibility of reconciling the vision of a universal humankind with a moral community. The only way to avoid the instrumentalization of community building and countercultural triumphalism is to see MCF as a space where human beings 'work out their salvation with fear and trembling' (Phil. 2:12) without hidden boundaries between those who have 'arrived' and those who are still 'on their way'. Building community means entering 'holy ground', that is, the space where the triune God is active. It is through community building that God involves us in his redemptive mission, i.e. saves us.

\section{Practices}

In a world rife with hostility, a challenge for MCF is how to be prophetic without being self-righteous. Christopher James labels as a particular weakness of some praxis-oriented churches their tendency to define themselves in opposition to evangelical churches. In other words, their mission may often be a rejection of orthodoxy rather than an embrace of orthopraxy. Many participants in such churches have been wounded by previous experiences with religious coercion and exclusion, which may explain their strong preference for non-authoritarian conversational and dialogical styles of learning. Here, echoes may be heard of Philip Wall's analysis of some praxis-oriented communities in the UK, where leaders who were raised in Evangelical environments had become so wary of an authoritative and exclusive Christian pedagogy that they failed to instil a genuine conversation between the Christian tradition and the 
questions and experiences of participants. This wariness is seen, among other things, in a 'disdain for evangelism. ${ }^{59}$

While this knot is too complicated to unravel here, the disdain may have to do with - at least partially - a view of evangelism as a 'vertical' message of doctrinal truth that must be accepted in order to be 'saved'. However, if witness is relocated in the way we have explored above, in the midst of an actual struggle with our impotence in the face of reconciliation, then evangelism itself may be restored as well to its original unity of witness on the Way of Christ. Evangelism, then, is not focused primarily on moving people to accept certain truths for truth's sake, but on the question what one needs to believe in order to become a person of peace.

Again, the central question is how we can become people who are capable of friendship with those who are not like us. And this question will inevitably reorientate us towards a series of classic and contemporary practices. How can community emerge without shared meals, hospitality, sharing possessions, parties, celebrations, mourning? Which practices will shape us to develop humility, self-discipline, honesty, love for enemies? Should we wash each other's feet? Is there a place for tithing? How can we learn to discern God's presence in our neighborhood? Should we have prayer-walks? In what ways will prayer, meditation, and shared reflection on texts and testimonies help us to become more loving and peace-minded? Which practices will help us to deal with failure, sin, and evil? Should we go out and protest? How do we do this in a way that is humble and loving? Which liturgies will make us more aware of the past sins of the church without becoming bitter, cynical or hopeless? How can leadership foster reconciliation?

\section{Conclusion}

In this article we have made three major points. First, we have argued that the implicit soteriology of MCF is best understood as a social soteriology. Secondly, we have advocated that this view of salvation provides an integrative lens on various dimensions of salvation expounded in Christianity. Thirdly, we have discussed how this view reemphasizes the importance of witnessing about Christ.

The view of reconciliation we have worked out here is unashamedly Christian. Yet, in order to be good news it must also be relevant. We believe that building community is a desire that finds echoes among people from

James, Church Planting, pp. 166-167. 
different worldviews. The attempt to build community among different people is a potential platform for respectful, humble dialogue about the beliefs that drive us and the practices that we are involved in. While there is no reason to be naïve about the gaps that divide us from each other and from the rest of creation, building community appeals to our shared humanity. It may resonate with 'what is desired by all nations' (Haggai 2:7). At the same time, this vision of God's future offers ample opportunity for prophetic challenge. In being radically committed to community building, missionary Christians will encounter ridicule, suspicion and criticism. Yet, such criticism will not drive them into a counter-cultural corner of society. Many people in our post-Christian societies share this dream of peace at least to some extent and recognize that this mission of reconciliation is, in the end, not an invitation to become more religious but to become more human. 